\title{
Vicious Circle Analysis of Poverty and Entrepreneurship
}

\author{
${ }^{1}$ Siti Rohima, ${ }^{2}$ Agus Suman, ${ }^{3}$ Asfi Manzilati, ${ }^{4}$ Khusnul Ashar \\ ${ }^{1}$ Academy Permanent Secretary of the Faculty of Management (ASM) Palembang Srivijaya and Extraordinary \\ Lecturer Faculty of EconomicsSriwijaya University, Indonesia \\ ${ }^{2,3,4}$ PDIE Lecturer, Faculty of Economics and Business, UB Malang, Indonesia
}

\begin{abstract}
Spirit of regional autonomy is reflected by most of the area on a desire to split away and form regions (regions) of new or new districts. One of the new sub-division is the result Distric of Alang-Alang Lebar. Ideally, the division of an area whether it be for the provincial and district and city, is expected to accelerate the development so that social welfare will increase. But in reality the division is carried out can lead to gaps and inequalities in society. and the rise of poverty.

Poverty is a very complex problem. So many ways that has been done by the Government but not yet provide optimal results. Poverty can be caused by internal or external factors. In general, poverty will cause people to be in bondage as a vicious cycle of poverty.

Research studies conducted in the District of Alang-Alang Palembang. This study is a qualitative study using interaksionime symbolic approach. In interaksionime symbolic of human behavior and interaction shown by the symbol and meaning, and should be able to translate the meaning and significance of the symbol.

This study produced a model cuts a vicious cycle of poverty through the entrepreneurship of the poor. The existence of entrepreneurship makes poor people more confidence to rise from the bondage of poverty and the cycle of poverty. So that the poor are able to get up and independent (entrepreneurship) and able to improve their lives and achieve prosperity
\end{abstract}

Keyword: Vicious circle of poverty, entrepreneurship, prosperity

\section{Introduction}

Along with the reform of governance in the area to change with the implementation of regional autonomy broadly, real and responsible. The spirit of local autonomy is reflected by most of the area on the desire to split away and form area (region) or sub new. One of the new sub-division is the result of District Alang-Alang Lebar. Ideally, the division of an area if it is for the provincial and district and city, is expected to accelerate development so that social welfare will increase. But in reality the division is done can cause gaps and inequalities in society (Rohima, 2009). Inequality and this gap is due to differences in resources owned and readiness of different human resources in each region. Ultimately, this will lead to inequality and the gap between the rich - the poor in the society so that the gap that occurs and lead to greater poverty.

The phenomenon of poverty is not a new issue, but the issue that seemed timeless throughout the ages. Poverty is the result of a process of impoverishment that occurs substantially consecutive, intertwined with each other. Substance poverty lies in the gap. The gap in question is the inequality of access available to all segments of society with relatively equal portions. Access is often only be reached by a particular layer, while others are very difficult to get it. Increasing urban poverty caused by high rates of urbanization and population mobility is very high. This condition causes the human population living in urban areas will take over the concentration of the population who had been living in rural areas for the first time. Thus due to rapid urbanization, the poverty rate in city will increase rapidly.

Urban poverty is one of the development issues are complex and contradictory (Irawan, 2002). Poverty is seen as spillovers from development and part of the problem in development. The existence of poverty is characterized by unemployment, underdevelopment, and inequality between regions. According to the Fatchudin Staley (2002), poverty stems from the fact that the total population of very low productivity due to lack of capital, markets are not perfect and economic backwardness. Sumodiningrat (2002) says, there are two main factors causing poverty and helplessness (powerless), the internal factors and external factors. Internal factors related to the constraints of poor individuals or society in question, such as low motivation, work ethic, lack of capital, lack of management control and technological aspects. External factors include not conducive institutional aspects in addition to still lack the infrastructure and support of the other so that the potential of the communities can not be fostered and developed.

Basically typology of urban poverty is characterized by multiple dimensions, both social and economic dimensions of a more diverse and has a complicated policy. It is a pattern of different poverty. According to Max-Neef et. al, there are 6 kinds of poverty is borne by the community and form a specific pattern of poverty, namely (a) subsistence poverty, low incomes, long working hours, poor housing, high water facilities, (b) protection of poverty, poor environment (sanitation, means of waste disposal, pollution), poor working 
conditions, there is no guarantee of land rights, (c) understanding of poverty, poor quality of formal education, limited access to information that the limited awareness of rights, the ability and potential to pursue change, $(\mathrm{d})$ participation poverty, lack of access and control over the decision-making process concerning the fate of self and community, (e) the identity of poverty, lack of integration between social groups, fragmented, and (f) freedom of poverty, stress, a sense of helplessness, insecurity both at a personal and community level.

Distric Alang- Alang Lebar can not be spared from the phenomenon of poverty. Poverty in District Alang-Alang Lebar shown by the community group in the category of poor families caused by the limitations of economic, social and political life of their poor families. This phenomenon is demonstrated by the presence of several heads of families who are economically unable to meet the primary needs of family members and have no permanent job. In addition, low levels of public education so that they are difficult to get a job with adequate results or provide for his family. There are also a number of families whose low level of health that is hindering their work.

District Alang-Alang Lebar is the result of new sub division divided into 4 (four) villages include Srijaya Village, Village of Alang-Alang Lebar, Talang Kelapa Village and Karya Baru Village. The number of poor people in the District of Alang-Alang Lebar 9231 people (2007), 10,342 people (2008), 13,556 people (2009), 17,032 people (2010) and in 2011 increased to 20,887 persons, while the total population of AlangAlang Lebar as 83,853 people (District Data, 2011). The number of poor people in District Alang Alang shows an increase each year in line with the increase of population. The population increased not only influenced by the birth rate but also influenced by the movement of people (immigrants).

There are some communities in the District of Alang-Alang Lebar life with sufficient, but there are some people living in deprivation. Regions with urban activities (trading and service activities) which causes minimum low economic communities. Based on the data obtained from the District Office of Alang-Alang Lebar, there are 20,887 souls of 83,853 souls who live below the poverty line. At $24.9 \%$ of the population in the District of Alang-Alang Lebar into the category average poor family of the poor have difficulty in meeting the needs of food and shelter. Economically, the revenue generated by the poor in servei for 300000-700000 (District Data, 2011). Approximately $80 \%$ of the income is spent to purchase food and beverage needs. This situation is quite alarming, because it has a huge impact on the level of health, education and hamper access to public services.

Therefore, to address poverty and inequality reduction that occurs there should be an act of improving standards of living in a way to minimize the factors contributing to the poverty of local communities. The study was conducted in an attempt to analyze the causes of poverty so that factor will be able to provide solutions to reduce poverty is happening so that people are able to rise from adversity and poverty.

\section{I.1. Problem}

The lack of revenue derived from the portion of the population whose livelihood does not cause the majority of the population remained in the District of Alang-Alang Lebar into the category of poor families. Given the extent of the theme of this research, it is necessary to set the focus and discussion so as not to widen. Building on the situation and conditions of the increasing number of poor people in Alang Alang Lebar Palembang today, this study focused on the analysis of the cycle of poverty and entrepreneurship in the District of Alang-Alang Lebar?

\section{II.1. Theory and Concepts Poverty}

\section{Literature Review}

According to Chambers (1983), poverty-related problems of social deprivation, access to resources such as water, shelter, health and sanitation, education and transportation. Chambers (in Suryawati; 2005) states poverty is an integrated concept that has five dimensions, namely: (1) poverty (prover), (2) powerlessness (powerless), (3) the vulnerability of emergency (state of emergency), (4) dependence (dependence), (5) isolation (isolation) both geographically and sociologically. Living in poverty is not only lack of money and living in a low income levels but also many other things, such as health, low education, unequal treatment under law, criminal threat vulnerability, powerlessness and helplessness in the face of the power to determine his own destiny. According Spicker and Gaiha (1993) that poverty is better understood together - together with other social problems such as hunger, disease, unemployment, overpopulation, environmental destruction, as a result a result of social conflict. Views on the various dimensions of poverty and mitigation opportunities categorization stems from absolute poverty and relative poverty. Absolute poverty refers to the minimum level of subsistence and livelihoods so that people can meet the needs for life. Central Bureau of Statistics (CBS, 2000), defines poverty standard poverty line (poverty line) of food and non-food. Food poverty line is the value of the basic needs of food consumption expenditure is equivalent to 2100 calories per capita per day. Non-food poverty line is the amount of dollars to meet the minimum needs of non-food items such as housing, health, education, transport, clothing and goods / services. 
Sajogyo (in Mudrajad, 1997) describes the rate of return to measure rice equivalent per capita expenditure per year for the category: urban poor rural $480 \mathrm{~kg}$ and $320 \mathrm{~kg}$, once in poor urban and rural $360 \mathrm{~kg} 240 \mathrm{~kg}$, the poor in urban and rural $270 \mathrm{~kg} 180 \mathrm{~kg}$. While BKKBN, using the unit for measuring household poverty. Poverty is at Pre Prosperous families (Pre-KS) and Family Welfare I (KS 1) characterized by difficulty meeting the needs of economic and non economic. Besides referring to individuals and households of the poor, poverty measures also approached through observation of poor areas. There is a strong relationship between the poor with the poor, so that by knowing the poor region can be expected to be found the majority of people are poor.

This is reinforced by the revelation of Sharp et al (1996 in Kuncoro 2000) identify the causes of poverty that occurs in the community, which is divided into three perspectives. First, poverty is due to the differences in the pattern of resource ownership leading to unequal distribution of income. The poor only have very limited resources with low quality. Secondly, poverty emerged as a result of differences in the quality of human resources. Low quality of human resources that will lead to low productivity that would result in low levels of wages. The low quality of human resources caused partly by a lack of education, the fate of the less fortunate, the existence of discrimination and heredity. Third, poverty appears as a result of differences in access to capital. This can be explained by figure 1 belows:

Figure 1

Cause of Poverty

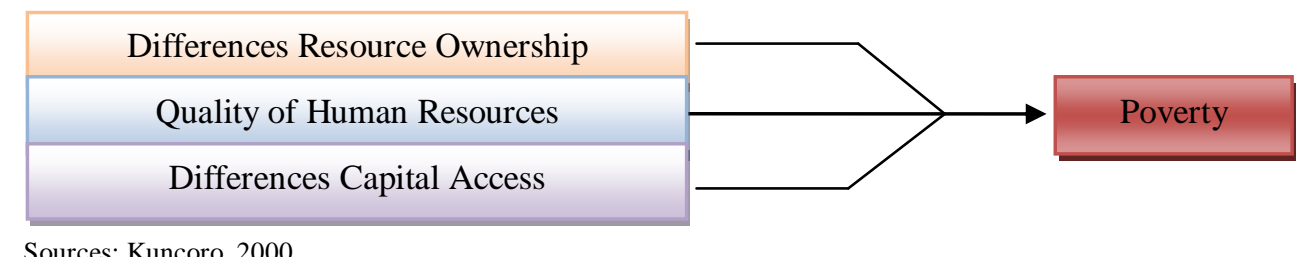

Another theory that further clarify the phenomena of poverty and contributing factors is the theory of "cycle of poverty" (vicious circle of poverty) are expressed by Nurkse which has significance in theory is the "State is poor because he is poor" (poor in a poor country is poor Because ti). According to Nurkse (in Jhingan, 2004). Causes of poverty by Kuncoro (2000) as follows:

1. At the macro level, poverty arises because of the inequality of resource ownership patterns that cause unequal income distribution, poor people only have the resources in a limited number and low quality;

2. Poverty arising from differences in the quality of human resources due to the quality of human resources means low productivity is also low, wages were low;

3. Poverty exists due to differences in access and equity.The three causes of poverty that leads to a vicious cycle of poverty theory (vicious circle of poverty). Logical thinking otherwise cited Kuncoro Nurkse (2000) which states that poor countries are poor because he is poor (a poor country is poor Because it is poor). The phenomenon of poverty will continue without letup intertwined and mutual influence one another in a circle can be seen in Figure 2.1, as follows:

Figure .2.

The vicious circle of poverty

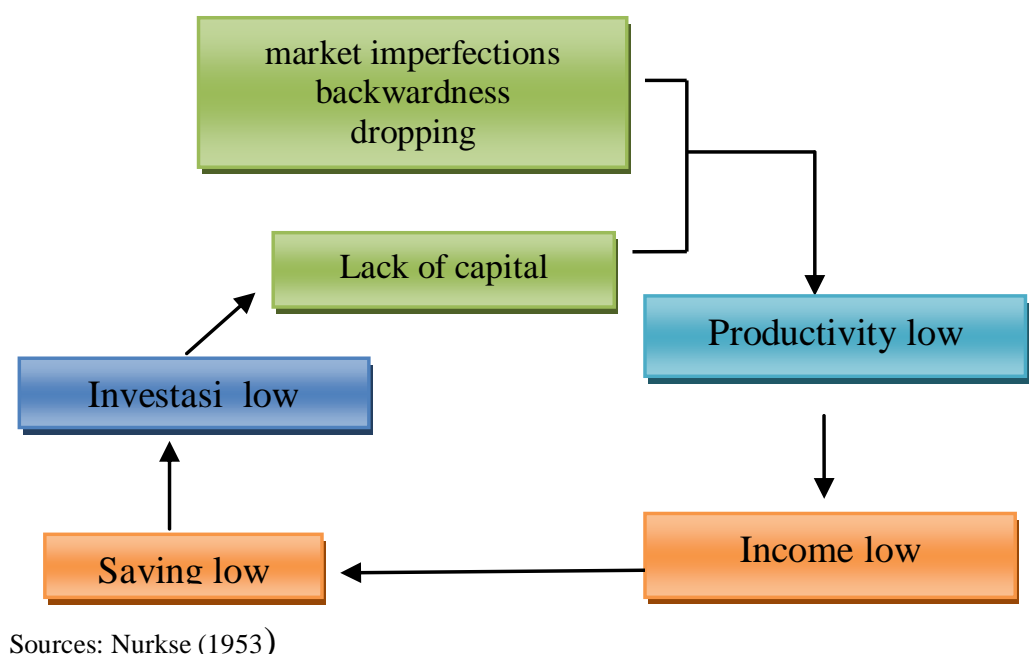


The process begins with the poverty of the retardation / underdevelopment, and lack of capital market imperfections. Of these factors affected the low productivity of the total population. Low productivity results in lower incomes of the poor receive. The low income will have implications for the low savings and investment trend lower. Subsequent impact, low investment will further aggravate the economy and result in socioeconomic underdevelopment and backwardness of the community. Therefore, every effort should be concentrated on the fight against poverty "cut" the circle of poverty traps (Kuncoro, 2000).

\section{II.2. Entreprenuership}

Entrepreneurship term, actually comes from the word entrepreneur. First used by cantilon in, Husaini (2004) essai sur la nature du commerce (1755), which called for traders who buy goods in these areas and then resell it at a price that is not definite. Understanding Entrepreneurship relative vary between experts or sources of reference with emphasis attention or a different emphasis. According Sutanto (2002), Entrepreneurship is often defined as someone who understands and can distinguish between opportunity and use it to their advantage. More broadly, Entrepreneurship is defined as the process of creating something different value using the effort and time required, assume financial risk, psychology, and the accompanying social and received monetary rewards and personal satisfaction.

Further Entrepreneuship can be interpreted also as attitudes and behaviors that are able to combine elements of independent creativity, taste, and intention as well as work or be able to combine elements of creativity, challenge, hard work, and satisfaction in order to achieve maximum performance so as to provide maximum value to the services, goods, and services generated with regard joints society. According Soesarsono (2002), Entrepreneuship is a profession that arise due to the interaction between the knowledge gained from formal education with art that can only be obtained from a given series of work in practice.

An entrepreneur is a person who is important in the production management problems. He should have extensive knowledge about the environment and makes decisions and determination in managing their business, managing a number of capital and face the uncertainty of the profits. Josep Schumpeter in Husaini (2004) provide restrictions Entrepreneuship as "Entrepreneurship is the prime creative force in society Socioeconomic," while the entrepreneur as "Entrepreneur is innovator, carrying put new combination." Clelland (1987) in Tawardi (1999) mentions traits possessed attitude Entrepreneuship is resemblance to persons with achievement motives (need of achievement) that is constantly trying to get better results than what has been obtained, willing to take risks at the level of the average, have a personal responsibility, and always want feedback results work to evaluate and improve future actions. McClelland (1987) in Husaini (2004) proposed the concept of N-Ach which stands for need for achievement (N-Ach) is defined as a virus that causes a person's personality always wants to do good and have a realistic goal by taking risks that have actually been taken into account.

Much research has been done on the characteristics that have always appeared on the behavior of a successful entrepreneur. Successful entrepreneurs have many of the same ways, among others, full of energy, innovative, willing to take risks and the desire to excel, but it is also the nature optimistic and believe in the future. Meredith et al. (1987) in Tawardi (1999) suggested that the characteristics of someone who has an attitude Entrepreneuship namely: a) flexible and supple in the mix, b) is capable and able to take advantage of business opportunities that exist, c) have the foresight, clever and cunning, d) respond to changing circumstances and uncertain, e) have confidence and be able to work independently, f) have an optimistic outlook and dynamic, and has exceptional leadership, g) has a strong motivation to get the job done properly and firmly the establishment, h) prioritizing achievement, and take into account the factors inhibiting and supporting, i) has a high self-discipline, and j) took a risk by taking into account the failure rate.

Entrepreneurs are individuals who dare to take risks, coordinating, managing investments or production facilities as well as introducing new functionality or production factor that is able to respond creatively and innovatively. Entrepreneurs are creating a new business to take risks to achieve profitability by identifying opportunities and combining the resources required (Zimmerer and Scarborough, 2002). Hisrich and Peters (2000) states that berentrepreneur means the process of creating something different by devoting all his time and energy with bear financial risk, psychological, social, and receive remuneration in the form of money and personal satisfaction. Drucker (1996) defines Entrepreneuship the spirit, skills, attitudes, behaviors of individuals in dealing with business or activity directed to find, create, implement ways of working, new technology and products to improve efficiency in order to provide better service and make a profit or greater. The advantage gained by developing creativity owned and discover new things. Entrepreneurs are not investors, struggling with uncertainty and risk, an entrepreneur always looking for change, respond and take advantage of the opportunity.

According Suryana (2001) Entrepreneuship is an ability to think of creative and innovative behavior (creating something new and different) basis, resources, tips and processes to create value-added goods and services, conducted with the courage to take risks. According to Meredith et al (1996), Entrepreneuship means dispositive blends personal, financial and resources. Entrepreneuship is the spirit, attitude and ability of 
individuals and businesses in handling or working towards searching, creating, implementing new ways of working, new technology and new products or value-added goods and services. Entrepreneuship a job or career that is flexible and imaginative, able to plan, take risks, make decisions and actions to achieve goals.

According Siagian (1996), Entrepreneuship is spirit, behavior and the ability to respond positively to the opportunity to benefit yourself and or a better service to customers or the public, always trying to find and serve customer better and better, and create and provide products that are more useful, implementing a more efficient way of working, with the courage to take risks, creativity, innovation and management capabilities. As'ad (2003) defines as the ability and attitude Entrepreneuship independent, creative, innovative, resilient, farsighted, risk-taking that is and without prejudice to the interests of others in their field or community.

Entrepreneuship scope includes two factors, namely human and social factors or civilization (Herath, 1998). Societal and civilizational factors require extensive specialized study and has not been allowed to do the research, then the discussion we will further detail is the human factor. Based on the various definitions that have been proposed by the experts, it can be concluded that Entrepreneuship is the spirit, attitude and ability of individuals and businesses in handling or working towards searching, creating, implementing new ways of working, new technology and new products or value-added goods and merit.

\section{III.1. Symbolic interactionism approach}

\section{Methods}

Research in District Alang Alang Lebar is a consequence selection of qualitative research methods interaksionosme symbolic approach. This means prioritizing the disclosure of a social phenomenon on the implications of self-empowerment of the poor on welfare.

Although individuals in the general economic outlook is rational, but rationality is limited. According to Lin (1999 in Manzilati, 2009) stated that individual rationality in a limited or restricted by the capabilities of the physical nerve (neurophysical ability) and the expense mempeoleh information. Physical limitations associated with the ability to receive, store and retrieve, and process information as well the ability to create knowledge and language understandable feelings of others, while the costs associated with the cost of obtaining information as a source of information in decision-making at every possibility.

Some of the issues raised previously allowed answered using several methods such as surveys and symbolic interactionism. In addition, according Wignjosoebroto, (2002 in Manzilati 2009) states that human life is semiotics (symbols and signs), the object is no longer limited to the visible, but also the behavior which is basically a reflection of the pattern of social structure macro, holistic and normative . Contrary to the state of the field that contains the economic phenomena with non-economic phenomena, the research on self-empowerment through social capital on poverty is not positivistic approach. This is because aside positivistic paradigm of symbolic reality intangible qualitative and quantitative didatakan unable to mathematical logic.

In this case, researchers prefer Interaksionalisme Symbolic (in line with the view of homo sociologicus) as well as the survey is considered accurate to measure the behavior and usually there is a problem and the response. Surveys are a good way to collect data on the perceptions, opinions and ideas, but this method is less accurate in measuring the behavior because of what people say about what they are doing may or may not reflect what they actually do (Manzilati, 2009). This approach is expected of an attempt to obtain information as possible about the various phenomena seutuh self-empowerment of the poor, to understand what they are doing, look at the interaction in an effort to use social capital so researchers as if present in their environment.

Furthermore, Blumer (1969) states symbolic interaction is a scientific perspective for understanding society and human behavior. This perspective is based on the view, man is a person who is active and creative, constantly engage in social interaction with people or the environment, as well as with yourself. Result of interaction with self diengaruhi several factors such as the concept of self (self concept), past experience (the same object) and destination. These factors will determine individual actions either individually or collectively or represent an organization is always oriented to the achievement of certain goals. Orientation, on the one hand, the interaction with the significant others are also very instrumental in the formation of meaning, because it can be generated from the interaction perspective. Therefore, a perspective that has been owned by the object to be understood.

In this study, symbolic interaction relate to how the poor to empower themselves, to interpret every gesture or symbol of the other party and do activities based on the meaning and interpretation of the results of these signs or symbols (Burrell and Morgan, 1979). The most fundamental propositions of symbolic interaction is a behavior and human interaction can be distinguished as shown by symbols and their meanings. Symbols are important aspects that enable people to act in ways that typical humans do.

\section{III.2. Research Sites}

This study focused on using a qualitative approach (Basrowi and Sukidin. 2002). In a study on the identification of poverty in District Alang Alang Lebar of Palembang provide a clearer picture of the factors causing the poor. Conditions of poverty, which is defined as a condition characterized by powerlessness of lack 
of access to economic, educational, health, and access to self-actualization is also seen from the mobility of the population, work ethic, self-behavior and socioeconomic backgrounds. Furthermore, Palembang issued Local Regulation no. 20 Year 2007 on Expansion District in the city of Palembang. One of the new district resulting from the division are: Alang-Alang Lebar. The establishment of district aims to improve the effectiveness and efficiency of governance based on demographic considerations and area. The purpose of the establishment of new districts in an effort to improve service to the public, perform the functions of government and community empowerment are based on the number of population in the district. District Government Center Alang-Alang Lebar domiciled in the Talang Kelapa Village. District Alang Alang Lebar, Palembang, addition, has a very strategic position and easy to reach. Distance District Alang-Alang Lebar toward provincial capital is only 1.1 $\mathrm{km}$ and the furthest village reaches a distance of $5 \mathrm{~km}$ from the district Alang-Alang Lebar. As a result a new sub division of District Alang-Alang Lebar has an area of 34.581 hectares wide and is the fourth largest district compared to other districts in the city of Palembang. District Alang Alang Lebar of four villages namely Srijaya Village, Alang-Alang Lebar Village, Karya Baru Village and Talang Kelapa Village.

\section{III.3. Determination of Informants}

This study focused on the empowerment of the poor through social capital. Based on the determination of the informants in the process of collecting data of this study is the individual (self) poor people who live in deprivation and limitations As with key informants or informants (key informants). In addition to poor individuals as additional data (also can serve as a test of the validity of the data) were obtained from informants support the local government officials and agencies, intellectuals, public figures.

\section{III.4. Data Collection Methods}

Specifically, the captured data is data emic (look inside of human perception, mindset, attitudes, beliefs). Emic data is used to explore the process and experience to understand the perceptions and the context of the state of the terteliti. In addition, it is necessary that the data sensual supporting data (secondary data or quantitative data that can be censored). Therefore, data collection is done by using a flexible design so that the desired information can be obtained.

The data in this study were collected using several methods, namely: first, unstructured interviews (not using questionnaires). An interview is a conversation with a researcher intent here is to be able to explore in depth the rights of the case, allowing exploration of why people have a different point of view and can be used to avoid errors (questions that can not be replaced immediately clear when the interview took place).

Second, the observation (observations) from the field by trying to put investigators on the position of the terteliti da involved (participate) in the activity of the poor. This is so terteliti not "consciously" being studied (unobtrusive) so that the information obtained is really an attitude, perception and action are chosen by individuals who are doing self-empowerment. Third, the Written Sources. In addition to sources outside of words and actions that there are sources of support written sources also called 'literature'.

\section{III.5. Data Analysis Techniques}

As described earlier study using Symbolic interactionism method. Furthermore, Blumer (1969) states symbolic interaction is a scientific perspective for understanding society and human behavior. This perspective is based on the view that man is a person who is active and creative, constantly engage in social interaction with people or the environment, as well as with yourself. The procedure was developed based on a symbolic interactionist social psychological view, Mead's dominated by a view of social reality as a process rather than as static. Human and social rules are in the process of "going to be" not as complete fact (Poloma, 1984)

\section{Discussion}

In a narrow sense, poverty is understood as a state of lack of money and goods to ensure survival. In a broad sense, poverty is a multidimensional phenomenon or multiface. According Suparlan (1995) stated poverty can be defined as a low standard of living, ie the existence of a certain level of material deficiencies in the number or class of people compared to the prevailing standard of living in the community. Low standard of living is directly visible effects on health, moral life, and self-esteem of the poor were classified as poor.

Identification of poverty in this study further highlights the causes of poverty at District Alang-Alang Lebar . The problem of poverty comes as a result of policy development, especially rural-urban development is not balanced, so the impact on the development of the phenomenon of poverty (especially in urban areas). Development and regional divisions provide socio-economic changes in the structure of society of a region. This condition provides benefits to the development and progress of society, but there are times when people make segelitir treated unfairly. In the District of Alang-Alang Lebar Palembang, there are some people become poor due to the economic policies, including the expansion of political territory that is less favorable to the community. This condition causes people do not have adequate access to the resource-key resources required to 
carry out a decent living. As a result, people are forced to live under a standard that can not be human, both from the economic, physical fulfillment aspects, social aspects, this process of reciprocal and interdependent and interlocked ultimately cumulatively weaken the poor. This situation if not addressed will exacerbate the poor condition characterized by low work ethic, bad habits that must be done to sustain life when the protracted birth culture of poverty.

Poverty is essentially not only economic issues but more multidimensional with the roots of the problem lies in the economic system and Politic nation. District Alang-Alang Lebar Palembang, people become poor due to the economic policies, including the expansion of political territory that is less favorable to the community. This condition causes people do not have adequate access to the resource-key resources required to carry out a decent living. As a result, people are forced to live under a standard that can not be human, both from the economic, physical fulfillment aspects, social aspects, this ongoing process of reciprocal and mutually interrelated and cumulative mngunci and ultimately weaken the poor. This situation if not addressed will exacerbate the poor condition characterized by low work ethic, bad habits that must be done to sustain life when the protracted birth culture of poverty. Based on the data obtained in the field, while the identification of the causes of poverty seen in District Alang Alang Lebar is as follows:

\section{The attitude of compulsion from society.}

Along with the rapid development of the city and further development in various sectors, changes Stewardship land become more common, especially with the follow developments and business interests. It can be seen from the increasing number of agricultural lands, whether in urban, suburban and even rural agriculture in general is the principal livelihood of its inhabitants, who converted to industrial areas, recreation, shopping, real estate roads, offices and so on. Gradually there were mostly landowners (farmers) are forced to sell their land. Although at an agreed price. This is due to land owners (farmers) do not have any other choice. Likewise, the open roads to facilitate transportation and urban sprawl. Road construction on the other hand benefit society, but on the other hand there are some people who have to give up the productive assets of the poor lost. People who are affected landowners (farmers). The landowners (farmers) to obtain redress from the authorities who will do the construction. Such conditions do not provide the option to landowners (farmers) but a must they obey the rules (regulations) are there.

Informants informed, since there used to be widening the road taken by the government to carry out the necessary infrastructure development communities. But the poor (the owner) was compensation paid to the land is not suitable (no match), because the land belonged to the poor and used to make a living to make ends meet (productive assets). Conditions on the ground that there was not able to control the poor because it has no immediate stake in every decision is not based on the conscience of the poor as the owner, so that the poor feel no strength to fight but to submit to what is desired by a particular party.

An informant also stated that there were several strengths of the rulers and owners of capital who can afford to buy local assets. Landowners do not have the strength. The decision to sell the land that poor people do not make the people in the District of Alang-Alang Lebar is more prosperous because land proceeds to run out to meet the needs of the poor. Today, people who work on farms or hired from outside the farm laborers. Economic conditions worsened especially harvest less frequently because these conditions while the poor should pay land rent to the owner of the land. There are even some of the community that uses the sale of land of the poor for consumption such as home improvement, car purchase, paying debts, and so on.

The decision to sell the land that poor people do not make the people in the District of Reeds width is more prosperous because land proceeds to run out to meet the needs of the poor. Today, people who work on farms or hired from outside the farm laborers. Economic conditions worsened especially harvest less frequently because these conditions while the poor should pay land rent to the owner of the land. There are even some people who use the proceeds of the land of the poor for consumption such as home improvement, car purchase, paying debts, and so on.

Loss of productive assets is very confusing. There are some poor people who used to be farmers (owners) now became a laborer, and there are some that confusion to find a job. This is because farmers have no other skills. Condition, affecting revenues and earnings in meeting the needs of food, clothing and shelter. In the end there were some people live in poverty due to erratic income and minimum income. One example of land and compensation for land owners sometimes do not fit properly. Land acquisition and compensation for land owners sometimes do not fit properly. This has sometimes led to problems between the government and the owners themselves. Basically there are several factors that led to this situation, namely (a) The land broker (broker), (b) a convoluted bureaucracy.

Government in this case as the owner of infrastructure development should also calculate and consider compensation not only physical but also non-physical such as socio-economic recovery of communities affected by development projects. Moreover, it also attempts displacement (relocation) to the new location. This removal must also consider the readiness of the people who will receive the new arrivals on the ground in order to 
prevent social conflict between local residents and migrants. Another issue in land compensation is to determine the parties that would be compensated for any party affected directly and indirectly. In addition, the existence of third parties (including brokers and land speculators) who bought the land from the original owner, and eventually add to the difficulties for Land Acquisition Committee (government) and landowners. Things like this sometimes makes the owner of the land to be collapsed and his life no better than before.

\section{The attitude of the Voluntary Society}

People's lives in the District of Alang-Alang Lebar is one of the minimal activity of urban population working with diverse livelihoods. Most people lack the income derived by a resident led to the majority of residents in the District of Alang-Alang width into the category of poor families. Efforts are made to meet the needs by selling assets they still had. This was done to meet kebuthan live, to eat, even for the needs of school children. When the sale of productive assets will be burdensome to the community in the future.

Sudirja opinion, stating the reasons farmers to sell their land because of: First, look at the condition of paddy land can not be expected to produce optimal and second, the price of land in the vicinity of rapidly increasing; Third, the economic needs that can not be avoided, such as meals, school, and others. Land conversion itself does not have to do with selling it to others first, but can also be done by the owner of the farm itself. Sales tanahpun do with the price agreement between the owner (seller) and the buyer. Looks like the sale of productive assets is an alternative that is taken to meet the needs that must be met. It is considered as the only way to finance role in everyday life that could not be suspended again, such as the need to eat and the cost of school children.

\section{The Poor arrivals}

Talk about urban poverty, revealed by Gavin Jones (in Dorodjatun, 1986), which states that as a result of the migration of rural dwellers into the city (especially cities in Java), has increased the number of poor people are there because of two things: because naturally increase (more births than deaths) and because of rural-urban migration continues to grow (to find work)

Development in District Alang Alang Lebar increases. All facilities that are growing especially public facilities such as roads. The opening of roads and road maintenance have open access districts and increase the mobility of people and goods and to create easy connectivity between the sub Alang-Alang Lebar with the city, the city with the city, and the surrounding area.

The increasing mobility of people more and more immigrants began settling in the District of AlangAlang Lebar. Newcomers interested in starting to live in the District of Alang-Alang Lebar. According to Todaro (1970) migration decision is a response to expectations about income and that would be obtained in the city compared to that received in the village, and the possibility of obtaining a job in the city. Each immigrants scrambling to get jobs, services facilities, housing, water and electricity, food availability, and so on.

The presence of immigrants will bring some new problems. Conditions will bring changes related to social interaction, social organization and structure, social institutions, and social perception. Immigrants who come without the skills and productive assets will create new problems. Issues that will increase the number of poor people in Sub-Alang Alang Lebar. This is because not all of which can urbanizazition or managed to improve his life, none of them are failing so chose to stay back in the village, but not a few who still remained living in the city, although the conditions are very poor, so it's almost not able to set aside part of their income to saved. Not to mention the onset of traffic congestion and criminal cases as well as many seasonal beggars or beggars anyway. Because it is not easy to overcome the most important memerkecil should optimize the impact of urbanization through the potential development. This situation increased the number of poor people in SubAlang Alang Lebar.

Based on the data obtained from the District Office of Alang-Alang Lebar, there are 20,887 souls of 83,853 souls who live below the poverty line. At $24.9 \%$ of the population in the District of Alang-Alang Lebar into the category of poor families. The average of the poor have difficulty in meeting the needs of food and shelter. Economically, the revenue generated by poor families surveyed at 300,000, 00-Rp.750.000, 00 (District Data and Field, 2011). Approximately $80 \%$ of the income is spent to purchase food and beverage needs. This situation is quite alarming, because it has a huge impact on the level of health, education and hamper access to public services.

In general, the poor in the District of Alang-Alang Lebar own their home or rent (lease), able to eat at least 2 times a day, the floor is made of cement board is not regular or ceramic and not on the ground floor, and they tend not to have a regular job. Works that are not fixed are usually day laborers, looking for passengers in the terminal services, brokers, replacement services can sometimes be a motorcycle taxi or city bus kenek.

Many immigrants accumulate in a location that makes the density in the District of Alang-Alang Lebar, such as one in the Village Srijaya have a high enough density. The distance between the one and the other very tight, muddy, dirty and even vehicles can not enter to reach settlements. Even in the Village is prone to flooding 
because the area was once a swamp and then dumped along with the increasing number of residents. There are about 200 families in the village Srijaya which annually flooded, especially in the rainy season. Urban settlements are also very risky because there are 23 families residing in the high-power electrical grid. In addition, there are also people who have a very low income families so that as many as 220 of their environment tend to be less healthy and dirty (CBS, 2011)

\section{Culture Society}

The concept of poverty is not just, for example, the lack of money to make ends meet, but also about the mentality of the individual in life. Poverty always generate community behavior (forced) than the two important aspects of health and education. According to Lewis, the Suparlan (1984), identified in the culture of poverty (especially in urban areas), is a consequence of the high density, limited access-access to consumer goods, healthcare and educational facilities.

Culture of poverty can also be realized in the undifferentiated economic situation, the development of the economic system of money, wage labor, and production systems for profit. Similarly, the people who have weak social institutions to control and solve social problems and population, the impact on high growth and high unemployment. Culture of poverty is an adaptation or adjustment and the reaction of the poor to the poor marginal position in a class stratified society, characterized by highly individualistic capitalism, so that has most likely to have a culture of poverty is low stratified communities, experienced a drastic social change.

The public view implies all existing provision governing do not have to work harder. All that is done is determined. Enjoy live by wanted. Conditions such as these affirm Oji individuals relax and accept what is without going to work harder and work ethic will result in low productivity is very low. This condition will affect revenue. When the productivity of low means the income will be low. Earned income is used for consumption as needed. When incomes are low income will be exhausted in meeting the needs that it has no advantages. It is stated that the level of savings occur very low even none at all. Sometimes for consumption must be covered with a debt that will add to the burdens of life. Conditions like this will add to the deterioration of the poor and increase the number of people in need.

Poverty that exist in the District of Alang-Alang Lebar also affected attitudes of individuals in a society that reflects the lifestyle, behavioral, or cultural unwittingly trapped in poverty. This situation is a poverty culture (culture of poverty) that can be pushed further into poverty, with signs such as incompetence work, low savings rate, and extravagant behavior, and low work ethic is also a resigned attitude to the environment of poverty.

\section{Lack of Capital}

Ownership little capital and the ratio between capital and labor (capital-to-labor ratios) resulted in low productivity which eventually became the causes of poverty. District Alang-Alang Lebar there are some people who have the skills but not able to do a better activity to increase revenue. Such conditions are very difficult for the people to rise from adversity and poverty.

The poor find it difficult to obtain capital. Though the capital is one necessary for the poor to be able to improve the standard of living rise. The low capital, the poor live without being able to implement the skills they have. When banks borrow from the poor is difficult to obtain because the requirements are so complex and have to use collateral, while the poor do not have any guarantees in accordance with bank standards. The existence of public capital can develop skills possessed so that productivity can be improved. High productivity to increase revenue and help the poor of the slump.

\section{Lack of Education}

Resource poor communities in the District of Alang-Alang Lebar likely still low. Low levels of education can not be separated from the culture and the local environment. The low level of education of the poor is not only experienced by the head of the family only, but also to family members affected. Lack of education of the head of the family is not independent of family background and the state of society at a time. For the poor in this district, at a time not yet a requirement level of education is so important, especially when the condition of facilities and infrastructure that support, so people prefer to work.

In the District of Alang-Alang Lebar, there is a tendency of every level of school has decreased the number of students. Many underprivileged children do not continue their education to a higher level because of the absence of fees. The main factor that people do not continue their education due to family economic factors. In addition, parents were forced to utilize his power to help the family economy, or at least can thereby reduce the burden of the family. This demonstrates the ability of poor households to reach a very limited education. With the low level of public education is affecting the skills, mindset and mental attitude of the poor. In this work, the poor rely more on physical strength or power, so as to ensure the poor do not have adequate opportunity to seek other employment. 
The statement implies a low level causing the poor do not have the option to search for a better alternative employment. In a statement implied poor individuals seemed to be at peace with the position's education. This condition can also create individual self-surrender to the state, as proposed by Chambers. Furthermore Chambers stated, the poor are always in a state of helplessness due to the low level of education. Powerlessness in many ways including being in determining anything.

\section{Self Closing of Foreign Influence (incovert)}

Order and regularity of a community (at the community) is inherited from generation to generation. If the community had contact with another, it will happen then imitate each individual develops artificial results in accordance with the circumstances. In other words, to understand social relationships (between people, and between communities) are affecting each other. However, it is possible, although there is interaction, there is a group or community (for certain situations) that do not develop themselves, so stay on the patterns of life and static. As represented in the District of Alang-Alang Lebar, there is a very close community themselves from outside influences. This community used to be a migrant communities and domiciled in that location. Resulted in the closure of the outside influences that restrict network community and trust with outsiders.

As a result, the majority of this group lives in deprivation and poor and did not improve significantly. This poor communities isolate themselves from the outside when people come in they tend to be suspicious, so that the poor are less able to renew and poor because less able to form a partnership with another party outside the community. In line with the opinion stated Chambers individual poverty was due to shut down and are in isolation. This condition makes them cover themselves from outside influences and are always suspicious of anyone who visited the site. As a result they are shut down and seclude themselves fettered with their own community without wanting to know the outside world so they tend to have a lower standard of living than any other region. This resulted in a lack of information, network-and also communication with external parties that will affect the rest of their lives.

As a result, the majority of this group lives in deprivation and poor and did not improve significantly. This poor communities isolate themselves from the outside when people come in they tend to be suspicious, so that the poor are less able to renew and poor because less able to form a partnership with another party outside the community. In line with the opinion stated Chambers individual poverty was due to shut down and are in isolation. This condition makes them cover themselves from outside influences and are always suspicious of anyone who visited the site. As a result they are shut down and seclude themselves fettered with their own community without wanting to know the outside world so they tend to have a lower standard of living than any other region. This resulted in a lack of information, network-and also communication with external parties that will affect the rest of their lives.

Underdevelopment and poverty that emerged in the process of development is caused by an imbalance in the ownership of or access to sources of power. Long historical process that led to the power dis powerment, the suppression power in most societies, as a result people do not have adequate access to productive access is generally controlled by those who have power. In turn economic backwardness led them further and further away from power. That vicious circle is spinning continues. Therefore, empowerment aimed at two directions. First, let go of the shackles of poverty and underdevelopment. Second, to strengthen the position in the economic structure of society.

Conditions such as these bring the people in the Alang-Alang Lebar are in the shackles of poverty. Nurkse version cycle of poverty, poverty is caused by underdevelopment, and lack of capital market imperfections that cause low productivity. The low productivity that would result in lower revenue implications for the low savings and investment. This condition will continue to take place continuously.

So the effort is to cut the cycle of poverty, in an effort to cut the cycle of poverty can be done by increasing the entrepreneurship of the poor. Entrepreneurial spirit is able to provide the poor to rise from adversity and underdevelopment that always haunt the lives of the poor. So the poor to get out of the cycle of poverty and improve the productivity, incomes will rise, investments and standards of living.Cut the cycle of poverty with entrepreneurship can be seen in Figure 3. below: 
Figure 3.

Cut the vicious circle of poverty through entreprenuership

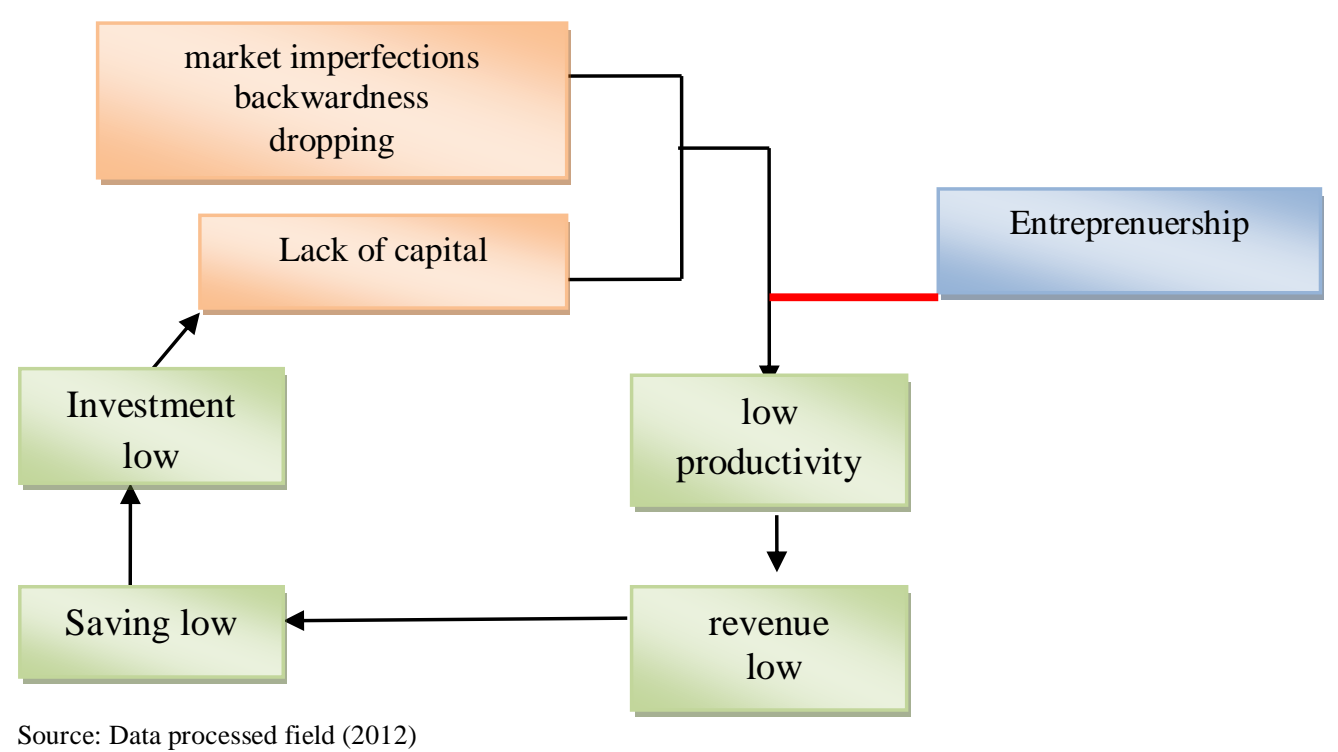

In making changes and improving the standard of living is a passion and one's attitude in dealing with business activities and character traits based entrepreneurs (entrepreneurship) that are reliable. Be aware that in everyone there is real potential is not the same level of entrepreneurship.

According to the American Models of Entrepreneurship focuses on the personal characteristics of the individual. The result is some of the characteristics that have been identified as key aspects to explain the entrepreneurial personality. The first character of the entrepreneur is the courage to take risks. Where entrepreneur entrepreneurship in doing the same as doing gambling, because the risks of doing entrepreneuship enormous. Entrepreneuship is the process of creating something new or developing the old things into something different, so it is likely the product to fail in the market is quite high. Entrepreneurs should be someone willing to take the risk. The second characteristic of the entrepreneur as an innovator. These characteristics reinforce theory expressed Schumpeter (1934) in Moore (1997) where entrepreneurs is someone who is able to innovate in terms of products, raw materials and production processes.

Characteristics next is a strong desire to excel. According to McClelland (1961) in Moore (1997) "That high need for achievement would influence the self-selection of an entrepreneurial position, defined as a salesman, management consultant or a business owner." Where a strong desire to excel is something that can inspire someone entrepreur position.

Another perspective of the entrepreneur is a manager. This was first revealed by adam smith (1776) in his book The Wealth of Nations in Moore (1997) and later modified by the thinker - other economic thinkers a century later. Around mid-year 1810 the industrial revolution, the main managerial ability affect entrepreneurial success (Say, 1967; Long, 1993: in Moore, 1997), then appeared the idea that an entrepreneur must be a manager (Knight, 1921; Leibenstein, 1968 in Moore, 1997 ). Another characteristic of the entrepreneur is an individual who made the change. Where individuals perform a simple transformation, which describes the idea of something done. Having a separate view in understanding the opportunity, rearrange and uncertainty to creatively create new products, new services, new organization and new ways to satisfy customers or conduct business (Birley and Muyzka, 2000 in Moore, 1997)

Entrepreneur has a value (Birley and Muyzka, 2000; Buame, 2000; Butler, 2003 in Moore, 1997). Entrepreneurs use and leverage resources to create products and services, aimed at satisfying customers and markets. The values are then to be in the process of transformation. There is a strong element of pull requests, but a true entrepreneur can sell ideas - new ideas and create demand.

Entrepreneur is a good network owner (Zimmerer and Scarborough, 2005 in Moore, 1997). Due to limited resources, especially financial, entrepreurs using creativity, social networking and a good supply, approval and action. Entrepreneurs are motivated to succeed; entrepreneurs have the determination and confidence. Second thing is the main reason for success: entrepreneurs refused to be defeated and survive the "going gets tough"

It is important to understand that the entrepreneur is a major figure in the entrepreneurial process. It can be found that the entrepreneurial process includes all functions - the functions, activities and events associated with the entrepreneur include creation opportunities and organizations that pursue these opportunities. Many 
researchers explain the entrepreneurial process as a dynamic and holistic process of activity and the strong desire of the people that make up the individual companies in an effort to empower themselves.

Furthermore, according to McLelland, in humans, there are three basic needs, the need for achievement, need for affiliation and need for power (Wiratmo, 1998). Need for achievement (N-Ach) is the drive to achieve the best results. N Ach gave birth to the nature of hard work, perseverance, never give up, dare to take risks, seek and take advantage of opportunities to obtain the best performance. Someone who has a high N Ach tend to be a successful entrepreneur. Need for affiliation is the need to establish a harmonious relationship and communication, keep the peace, tranquility, good friendships and keep in order to avoid conflict. Need for power is the need for power, an incentive to influence, organize and convince others, and are willing to follow. Thus the cycle of poverty that exist can be trimmed with entrepreneurship in the District of Alang-Alang Lebar, will give a positive value, include;

a. Confident. Individual "self" to empower themselves by having the confidence and courage to do business. The provision should be sought if it does not work will not eat. This situation is expected to grow the need for achievement which raised high work ethic, and love to work hard.

b. The courage to take risks; Dare to Take Risks. Meet and interact with others to have a positive impact when used to support and enhance knowledge and increase skills. Limited knowledge can be extracted more leverage with the social and interact with others. With the self-confidence enables motivated to empower themselves with new businesses as a source of revenue to improve the lives of themselves. Businesses that have pioneered more developed again to further increase revenue and be able to employ people in the vicinity. To start a business and take any risk to the business carried on.

c. Oriented tasks and outcomes; Increased knowledge and skills. Entrepneurship task oriented and results provide a great passion for the poor to rise. Networks give people a lot to have a partner. Thus giving the poor to increase the opportunity to learn from such friendships or colleagues. Skills acquired memalui not have formal education but the cost can be derived from friendship, so long as there is a willingness to learn from ignorance to know without any sense of pride and shame. The change from the poor to be willing to learn from others is an attitude that must be owned. It is possible that individual gain additional knowledge and skills of others that will be used to further the individual's life. This condition will be able to increase the skills of self.

d. Leadership. $\neg$ Able to lead well for himself and for others. A strong and honest leader in managing all activities. Increased work ethic. The existence of self-empowerment entrepreneurship supported by the network, confidence and work ethic to improve themselves so as to increase productivity and incomes and living standards. Work ethic is better than ever with appreciate the time that can be used in increasing productivity than just lazing. Individuals are able to have a view that "should not gawe half-life" means to be able to survive better then it should work with the maximum.

e. Originality: creativity and inovation. $\neg$ Having a creative and innovative spirit to innovate. The existence of the network itself adds insight. So in that empower individuals to make "self" self empowerment allows invidu to be creative by doing many were able to find new things that consumers do not get bored. This condition will be able to increase sales turnover. Empowerment will create invidu-independent individuals. Increased productivity will increase the revenue that will ultimately improve the welfare of individuals that will be able to do the saving and investment. Increased saving and investment will support the poor are able to expand their business and increase turnover of business carried on. Total turnover increased and more established businesses make poor people are able to rise from poverty. Thus, through self-empowerment will create a new atmosphere or climate that allows people to grow and strengthen the economic potential in overcoming poverty.

f. Oriented to the future. $\neg$ Always have insight and outlook for future progress. Always thinking ahead so that every effort will develop better executed. In addition, the positive side of the extent of the network provide for the expansion of a business in marketing their products. This situation will increase the sales turnover and expand production so as to increase income. Networking is very important for individuals who market the product. So the amount of product that can be sold to increase from year to year. Conditions will be improving the yield and increase the amount of income so that individuals empower themselves to improve the standard of living is better. Networking and self-confidence will facilitate in obtaining raw materials. Moreover, the easy self-confidence to pay back from raw materials purchased. Networking and cooperation between peoples. This situation will facilitate change efforts that improved people's lives.

Thus increasing entrepreneurial spirit of the poor in the District of Alang-Alang Lebar able to create a climate that enables the poor to be able to evolve and rise from adversity. Efforts to increase the economic resources do in order to create individuals who are independent and brave the risk of his decision and to increase productivity. The poor souls who have independence (entrepreneurship) will have an attitude of self-assurance, courage take the opportunity, do not be afraid to fail and always worked hard, tenacious and creative. Soul 
independence (entrepreneurship) is necessary for the poor to make changes and improve living standards. This situation will be able to strengthen the economic potential of the poor because it will use whatever power they have to prosper in some ways influenced by expectations about the future. Entrepreneurship can increase the productivity of the poor that will boost revenue. Revenue climbed will have implications for saving and investment. This condition makes the poor to make changes to its full potential to improve the standard of living so as to achieve prosperity as expected and rise from the bondage of poverty vicious circle (vicious circle of poverty).

\section{Conclusion}

Based on the findings of a field study in the District Alang-Alang Lebar unknown factor causes of poverty, consisting of (1) The attitude of compulsion from society, in this case people need to sell assets as it pertains to the situation facing both rulers (government) and owner of capital. Sale of productive assets is causing them to be poor because they do not have a steady source of income. (2) Voluntary public attitudes, in this case poverty is because people sell assets to meet their living needs. (3) Immigrants Poor, poverty in the District of Alang-Alang Lebar compounded by the presence of immigrants who do not have the skill and the skill and have no assets so they do not have enough income to make ends meet. (4) the culture, in the district is also influenced by the culture of poverty alleviation (culture of poverty) that can be pushed further into poverty, with signs such as incompetence work, extravagant behavior, and low work ethic is also a resignation environmental poverty. (5) Lack of capital, in the District of Alang-Alang Lebar there are some people who have the skills but are not able to do a better activity to increase revenue. (6) Lack of education, lack of awareness about education led many residents are able to continue their education to a higher level. This situation will affect the chances of obtaining a better job to increase income (7) concealed from Foreign Influence. These conditions resulted in individual lives and in the environment that limit the external network, lack of communication, and isolated so will result in living in backwardness. So that this condition brings people in the District of Alang-Alang Lebar in a position of poverty circle (vicious circle of poverty).

Therefore, to address the conditions of poverty that occurred in the District of Alang-Alang Lebar is necessary to do an act of improvement in the lives of local communities in a way to minimize the factors contributing to the poverty of local communities. Steps taken to cut the cycle of poverty is the creation by entrepreneurship spirit within poor communities. So when pruning cycle of poverty carried out in accordance with the causes, the fight against poverty can be made more optimal.

\section{References}

[1] Adi, Isbandi Rukminto, 2002. Thoughts in the Development of Social Welfare, Jakarta, LPFEUI

[2] Aldridge, Stephen. , 2001. Social Mobility-a discussion paper, Performance and Innovation Unit.

[3] Arief, Syaiful. 2000. Refusing developmentalism, Library Student, First Printing.

[4] Basrowi and Sukidin. 2002. Qualitative Research Methods Micro Perspective, Scholar Insan Surabaya, p.125

[5] Berenger, Valeria \& Audrey Verdier Chauchane, 2007. Multidimensional Measure of Well-Being: Standard of living and Quality of Life Cross Countries. World Development. Vol. 35, no. 7, pp 1259-1276

[6] Blumer, Herbert. 1969. Symbolic Interaction, PerSeptive and Method, Englewood Cliff. New Jersey: Prentice Hall, Inc..

[7] Bhatta, Gambhir. 1996. Capacity Building at the Local Level for Effective Governance: Empowerment without Capacity Meaningless. Papers. Manila

[8] Burell, Gibson and Gareth Morgan. , 1979. Sociological Paradigms and Organisational Analysis. Ashgate Publishing Company, USA.

[9] Central Bureau of Statistics, 2011. Poverty Indonesia, Jakarta

[10] Central Bureau of Statistics, 2011. In Figures Palembang, Palembang, p. $30^{\text {th }}$

[11] Candy, P. C. 1989. Alternative Pardigms In Educational Research. Australian Educational Research, Vol. 16 ${ }^{\text {th }}$

[12] Chafetz, Janet Saltzman. 1987. Primer On The Construction and Testing of Theories in the Sociology, Peacock Publishers Inc.

[13] Charon, Joel M. , 1998. Symbolic Interactionism. Perspektive and Method Prentice-Hall Inc.. USA, p. 6, 23, 70, 72, 135, 161, 163, 165,167

[14] Charon, Joel M. 1999. The Meaning of Sociology, A Reader (ed). Sixth Edition. Upper Saddle River, New Jersey: Prencite Hall.

[15] Chambers. 1987. Rural Development From Rear. Jakarta: LP3ES

[16] Charmaz, Kathy. 1995. Between positivism and Postmodernism. Studies in Symbolic Interaction, 17, p. 43-73.

[17] Chua, Wai Fong. 1988. Interpretive Sociology and Management Accounting Review, Vol. LXi, no. 4, p. $601-631$

[18] Chuzu, 2002. Social capita effect on rural poverty and technical efficiency Kawazula Natal South Africa. http://www.bepress.com/cg? Journal, March 20, 2011

[19] Coleman, James. 1986. Social Theory, Social Research and a Theory of Action. The America Journal of Sociology 91: 1309-1335

[20] Coleman, James. , 1998. Social Capital I The Creation Of Human Capital. The American Journal of Sociology 94, (Supplement): S95-S120

[21] Coleman, James. 1994. Foundation of Social Theory. Cambridge: Harvard University Press.

[22] Collins, Randall. 1985. Three Sociological, Traditions, New York, Oxford University Press.

[23] Conrad, C., et.al, 1993, Qualitative Research in Higher Education Needham Hights Ma; Ginn Press

[24] Collier, P, 1998. Social Capital and Poverty. Social Capital Initiative Working Paper No.. 4. The World Bank.

[25] Cox, E. 1995. A Truly Civil Society. ABC Books. Sydney Dasgupta, P. 1988. Trust as a Commodity in Gambetta, ed, Trust: Making and Breaking Cooperative Relations.Oxport: Blackwell.

[26] Davis, Anderson and Curtis, 2001. Measuring Ethical Ideology In Bussiness Ethics: Acritical Analysis Of The Ethics Position Questionnaire. Journal of Business Ethics. Vol. 32, p. 35-53

[27] Norman K. Denzin and Yvonna S. Lincoln (Eds). 1994. Handbook of Qualitative Research. Sage Publications. London. 
[28] Elster, John. 1989. Social Norms and Economic Theory. Journal of Economic Perspectives, no. 3, p. $99^{\text {th }}$

[29] Faisal, Sanapiah. 1995. Formats for Social Research. Jakarta: Eagles Press.

[30] Faturochman, et al. , 2007. Building a Movement for Poverty Reduction through Community Empowerment. New York: Center for Population and Policy Studies, Gadjah Mada University

[31] Francois, P, 2003. Social Capital and Economic Development. London: Routledge.

[32] Friedmant, Jhon. 1992. Empowerment The Politics of Alternative Development, Camridge Mass, Blackwell Publisher.

[33] Freire, Paulo.199. Pedagogy of the Pressed, New York, The Continuum Publisihing, Company.

[34] Freund, Julien. 1969. The Sociology of Max Weber. New York: Vintage Books. Waveland Press.Inc.

[35] Fu, Qianhong, 2004. Trust, Social Capital and Organization Effectiveness, Balcksburg, VA.

[36] Fukuyama, F, 1995. Trust, Social Capital Virtues and The Creation of Prosperity. Free Press. New York

[37] Fukuyama, F. 2002. The Great Disruption: Human Nature and the Reconstruction of Social Order. Yogyakarta CV. Qalam, p. 234 334

[38] Furchan, Arif. 1992. Introduction to Qualitative Research Methodology, Surabaya: National Business.

[39] Grootaert, C and Van Bastelaer. 2002. Understanding and Measuring Social Capital: A Syntesis of Findings and Recommendations from the Social Capital Intiative .. Washington. D.C, World Bank

[40] Grootaert, Christiaan, Deepa Narayan, Veronica Nyhan Jones, and Michael Woolcock. , 2004. Measuring Social Capital: An Integrated Questionnaire. Washington, D.C. : The World Bank

[41] Hardiman, F. Budi., 2003. Exceed Positivism and Modernity: Philosophical Discourse of Modernity Scientific Method and Problem. Yogyakarta, Canisius Publishers, p. $16^{\text {th }}$

[42] Hasbullah, Jousairi., 2006. Social Capital (Towards a Culture of Human Excellence Indonesia). Jakarta: MR-United Press, p. 6, 9

[43] Hajar, Ibn. 1996. Metodoligi Basics of Qualitative Research, Jakarta, PT. King Grafindo Persada

[44] Haug, Michaela. , 2007. Poverty and Decentralization in West Kutai: Impact of Regional Autonomy on Welfare Benuaq. Research Report. Bogor, Indonesia: Center for International Forestry Research (CIFOR), p. 10-20

[45] Hewitt, John P, 1991. Self And Society: A symbolic Interactionist Social Psychology. Fifth E dition. Boston: Allyn And Bacon.

[46] Hughes, John A. 1990. The Philosophy of Social Research (Second Edition), London and New York: Longman.

[47] Hendarso, Emy Susanti, 2007. Qualitative Research: An Introduction Prenada Jakarta, Media Group.

[48] Horton and Hunt. 1991. Introduction to Sociology. Jakarta: grants. 